BANCA D'ITALIA

E U R O S I S T E M A

Questioni di Economia e Finanza

(Occasional Papers)

The IMF Safety Net and emerging markets' sovereign spreads

by Claudia Maurini 

13 BANCA D'ITALIA

E U ROS I S T E M A

\section{Questioni di Economia e Finanza}

(Occasional papers)

The IMF Safety Net and emerging markets' sovereign spreads

by Claudia Maurini

Number 370 - February 2017 
The series Occasional Papers presents studies and documents on issues pertaining to the institutional tasks of the Bank of Italy and the Eurosystem. The Occasional Papers appear alongside the Working Papers series which are specifically aimed at providing original contributions to economic research.

The Occasional Papers include studies conducted within the Bank of Italy, sometimes in cooperation with the Eurosystem or other institutions. The views expressed in the studies are those of the authors and do not involve the responsibility of the institutions to which they belong.

The series is available online at www.bancaditalia.it.

ISSN $1972-6627$ (print)

ISSN 1972-6643 (online)

Printed by the Printing and Publishing Division of the Bank of Italy 


\title{
THE IMF SAFETY NET AND EMERGING MARKETS' SOVEREIGN SPREADS
}

\author{
by Claudia Maurini*
}

\begin{abstract}
This paper assesses empirically the effectiveness of the IMF as a component of the Global Financial Safety Net by running a panel regression on a sample of emerging market countries' sovereign spreads. In particular, we check if the size of the Fund's lending capacity and the introduction of the new precautionary facilities play a role in explaining emerging market countries' spreads, after controlling for the traditional determinants of the spreads reported in the literature. From a policy perspective, the empirical evidence presented in this paper can provide a basis for assessing the potential gains from a stronger role of the IMF and of the GFSN in general, an important issue in the current international debate. We find that what appears to matter most are the overall resources avail- able for lending by the IMF, rather than the channels through which such resources can be accessed by members.
\end{abstract}

JEL Classification: F33, F55.

Keywords: International Monetary Funds, Global Financial Safety Net, sovereign spread.

\section{Contents}

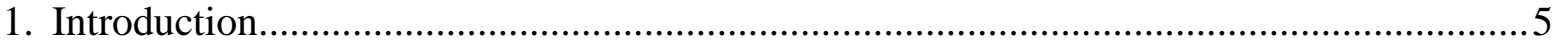

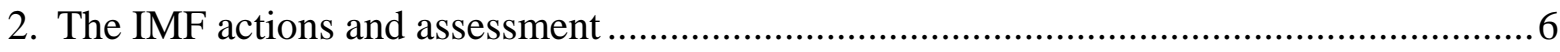

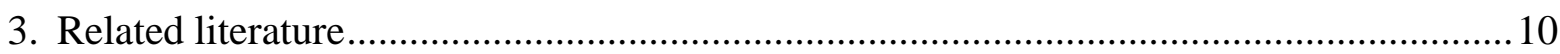

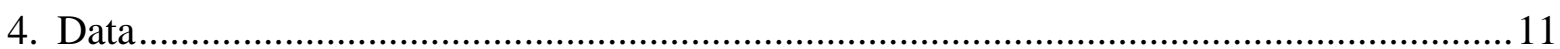

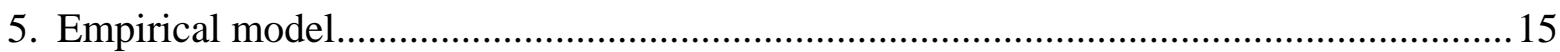

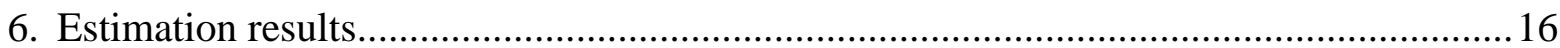

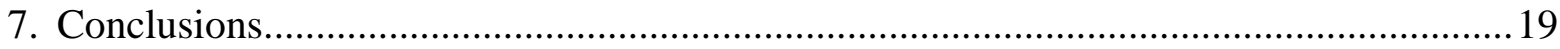

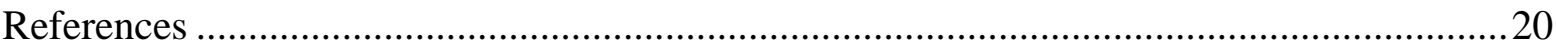

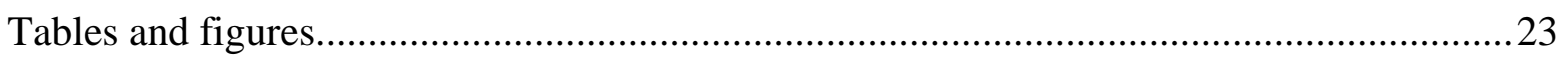

\footnotetext{
* Bank of Italy, International Relations Department.
} 



\section{Introduction 1}

In 2009 the international community, led by the Group of Twenty (hereafter G20), sought to provide a joint and credible response to the global financial crisis. At their meeting in London in April 2009, the G20 Leaders made a commitment to "fund and reform the international financial institutions to overcome this crisis and prevent future ones"2 ${ }^{2}$. On that occasion, G20 countries pledged to triple the resources available to the IMF to $\$ 750$ billion.

In March 2009, the IMF had already approved a major overhaul of its lending framework, including the creation of a new precautionary facility (the Flexible Credit Line, FCL), the doubling of normal access limits for nonconcessional resources and the modernization of conditionality for all borrowers.

The alleged effectiveness of these measures has subsequentely been used to justify a further expansion of the resources of the IMF for dealing with crisis prevention and resolution ${ }^{3}$

In the following years the debate has broadened to a more general discussion around the strengthening of the International Monetary System through, among other things, the enhancement of the Global Financial Safety Net (GFSN) $4^{4}$

The aim of this work is to test the effectiveness of the IMF as a component of the GFSN. More specifically, we perform a panel regression on a sample of emerging market countries' sovereign spreads and check whether Fund-related variables play a role in explaining spreads on emerging market

\footnotetext{
${ }^{1}$ I wish to thank Pietro Catte, Marco Committeri, Giuseppe Parigi, Francesco Paternò and Flavia Corneli for useful comments and discussion. The views expressed here are those of the author and do not necessarily reflect those of the Bank of Italy.

${ }^{2}$ Leaders' statement at available at www.imf.org

${ }^{3}$ In 2010, following up on the call by G20 Leaders in Seoul to explore the feasibility of a structured approach to coping with liquidity shocks of a systemic nature, the IMF proposed the creation of a "Global Stabilization Mechanism" (GSM) which would have enabled the Fund to collect a huge amount of resources from members and make them available to countries in risk of distress or contagion. However, the GSM never saw the light of day.

4 "The GFSN comprises a loosely connected network of country insurance and lending instruments encompassing multilateral institutions like the IMF, bilateral and regional financing arrangements, and individual countries own reserves that countries can draw on to cope with financing shortfall, volatility and contagion from a crisis" IMF (2014). For more details on the debate on GFSN, see the Palais Royal Initiative Report (2011), Truman (2013) and Denbee et al. (2016).
} 
countries' sovereign debt, after controlling for the traditional determinants identified in the literature. We focus on two aspects:

1. Does the size of the IMF (i.e. its resource endowment) influence the market perception of the riskiness of emerging market countries?

2. Did the creation of precautionary lending facilities in 2009 affect this perception?

The issues addressed in the paper are important from a policy perspective: our analysis could provide empirically grounded arguments for or against strengthening the role of the IMF and of the GFSN in general, an issue that is widely debated.

According to our findings, what seems to matter most is how much money is made available by the IMF for crisis prevention and resolution, rather than the channels through which such money can be accessed.

The paper is organized as follows. Section 2 describes the measures taken by the IMF in 2009 in response to the global financial crisis and reports the IMF's official view on their effectiveness. Section 3 surveys the most relevant literature on the determinants of emerging countries sovereign spreads. In Sections 4-6 we describe the data used for the empirical analysis and we then discuss the empirical model and the main findings of the analysis. Section 7 concludes.

\section{The IMF's actions and assessment}

At least two different key decisions taken in 2009 must be considered: on March 24, the IMF announced a major lending policy reform to help countries deal with the effects of the global economic downturn; on April 2, at the G20 meeting in London, the Leaders decided to triple the IMF resources, from $\$ 250$ to $\$ 750$ billion. In what follows, we describe these measures in greater detail ${ }^{5}$

\footnotetext{
${ }^{5}$ At the end of August 2009 the IMF also approved a general allocation of Special Drawing Rights (SDR) for an amount equivalent to $\$ 250$ billion. The SDRs are a potential claim on the freely usable currencies of the Fund's members: hence they represent a form
} 
Reform of the lending framework. The overhaul of the lending framework comprised several measures, the most important of which was the creation of the FCL ${ }^{6}$. This is a precautionary credit line that allows countries with very strong fundamentals, policies, and track records of policy implementation to draw on it at any time. Countries meeting predefined qualification criteria $]^{7}$ (the ex ante conditionality) are entitled to an upfront access to Fund resources with no ex post conditions. Access under the FCL is not linked to the country's quota and is determined on a case-by-case basis, only after a request has been made by the eligible country. The Fund does not publish a list of members eligible to use the FCL, reflecting its intent of containing the proportion of its resources pledged for precautionary purposes. Disbursements under the FCL are not phased or conditioned to specific policy understandings, as is the case under a traditional Fund-supported program. This flexible access is justified by the very strong track records of the countries that qualify for the FCL, which give confidence that their economic policies will remain strong.

So far three countries have requested the FCL: Mexico (April 2009), Poland (May 2009) and Colombia (November 2009); all of them have repeatedly renewed the credit line at its expiration, but none have yet drawn resources from the credit line made available by the Fund.

Resource increase. As a key part of the efforts to overcome the global financial crisis, on April 2, 2009, the G20 agreed to increase the resources available to the IMF from $\$ 250$ to $\$ 750$ billion to support growth in emerging

of unconditional liquidity, to be used to acquire strong currencies from other members in case of balance of payments need or to settle transactions and operations between Fund members and the General Resources Account.

${ }^{6}$ The other reforms regarded the modernization of conditionality, the enhancements of Stand-by Arrangements, the doubling of access limits and other minor modifications.

${ }^{7}$ The criteria for assessing qualification to an FCL arrangement include: (i) a sustainable external position; (ii) a capital account position dominated by private flows; (iii) a track record of steady sovereign access to international capital markets at favourable terms; (iv) a reserve position that is relatively comfortable when the FCL is requested on a precautionary basis; ( $\mathrm{v}$ ) sound public finances, including a sustainable public debt position; (vi) low and stable inflation, in the context of a sound monetary and exchange rate policy framework; (vii) the absence of bank solvency problems that pose an immediate threat of a systemic banking crisis; (viii) effective financial sector supervision; and (ix) data transparency and integrity. Strong performance against all of these criteria would not be necessary to secure qualification under the FCL, as compensating factors, including corrective policy measures under way, would be taken into account in the qualification process. 
market and developing countries. This goal was endorsed by the International Monetary and Financial Committee (IMFC) in its communiqué of April 25, 2009. The resource increase was made in two steps: first, through bilateral financing from IMF member countries; second, by incorporating this financing into the expanded and more flexible New Arrangements to Borrow (NAB) On September 252009 the G20 announced it had delivered on its promise to contribute over $\$ 500$ billion to a renewed and expanded NAB $9^{9}$

According to the IMF, in 2009 "the combination of larger resources and more flexible lending instruments helped mitigate the risk of tail events, thus contributing to a generalized and sustained reduction in emerging market spreads, which had previously remained stubbornly high despite a rapid decline in measures of credit risk in advanced economies" (p. 12, IMF, 2010). This claim was at the time supported by qualitative evidence conveyed by the IMF staff: as in Figure1, there was a decrease in spreads coinciding with the announcement of the tripling of resources and the creation of the FCL.

\footnotetext{
${ }^{8}$ The NAB is a credit arrangement between the IMF and a group of member countries and institutions through which the IMF borrows additional resources and increases its lending capacity to forestall or cope with an impairment of the international monetary system. The NAB has been activated multiple times without interruption between April 2011 and February 2016.

${ }^{9}$ The IMF's endowment was increased again in 2012 when, following the developments of the debt crisis in some euro area countries, a group of IMF members decided to pledge additional resources equal to about $\$ 460$ billion through bilateral loans. Those resources are meant to be a second line of defence and would be made readily available if the more traditional sources of financing (i.e. quota and NAB) were to prove insufficient vis-à-vis the global demand for financial assistance.
} 


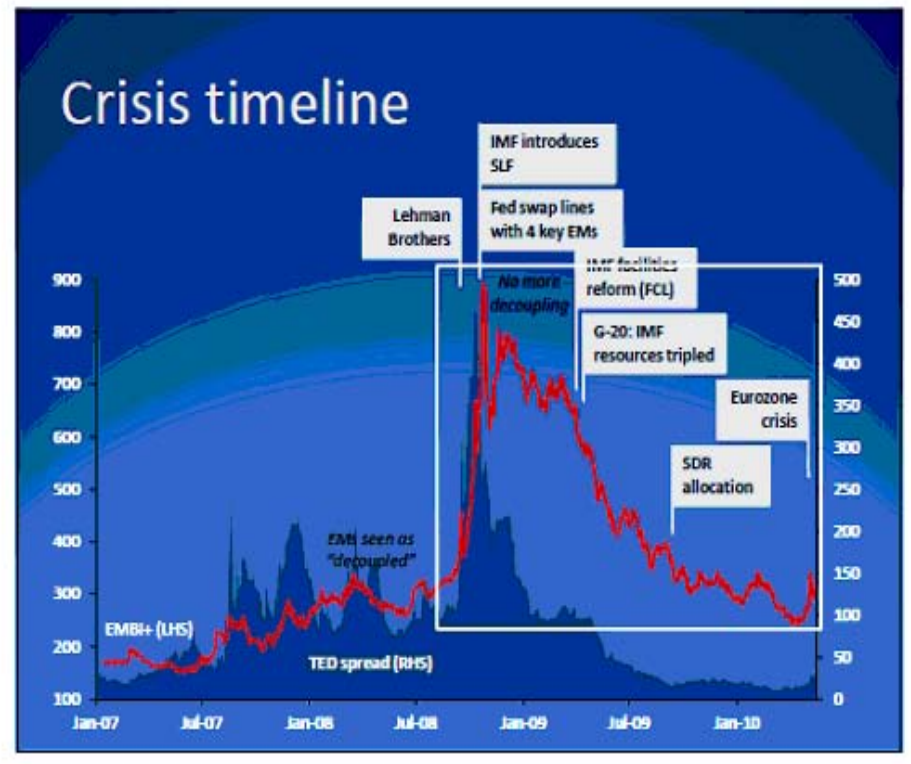

Figure 1: EMBI+ composite spread (LHS) and TED spread (RHS), 20072010. (Source: IMF Strategy, Policy and Review Department)

In IMF (2010) the only empirical reference cited to underpin this claim is an event study by Izquierdo and Talvi (2009), in which the authors compare the performance of emerging markets spreads during the recent global crisis and during the Russian/Long-Term Capital Management crisis of 1998. They conclude that the lower average spreads recorded in 2008-09 were due to the better fundamentals of emerging countries and to the readiness of the international community to provide financial support in case of liquidity problems.

At that time this view was challenged, for example, by Fernandez-Arias and Levy-Yeyati (2010), who underlined that the performance of the spreads of emerging markets with potential access to the FCL is indistinguishable from that of other countries 10

\footnotetext{
${ }^{10}$ The list of countries that potential have access to the FCL is not disclosed by the Fund; the authors define access as having prior spreads lower than the higher spread among explicitly approved countries (Colombia), and identify in this way a set of 13 countries.
} 


\section{Related literature}

Empirical research on the determinants of emerging markets sovereign spreads was developed starting in the 1990s, following the surge in bond issues by those economies and the subsequent debt crises, although most empirical work dates from the 2000s, when longer data series started to be available. In an early, seminal contribution, Edwards (1984) had found that the main drivers of the spreads are country-specific fundamentals, such as external debt, debt service and reserves. More recently, the literature has focused on two main issues: (i) identifying other explanatory variables, both global and country-specific; (ii) analysing the interaction between local and global factors.

As regards the literature on the determinants, in addition to Edwards (1984), Luengnaruemitchai and Schadler (2007) and Hartelius and Kodres (2008) identify as important drivers of spreads some global factors such as the level of international interest rates, market uncertainty and global risk aversion. Peiris (2010) concentrates on global liquidity conditions (measured by the level of long-term US Treasury yields) and foreign participation in local bond markets. Levy-Yeyati and Williams (2010) confirm the importance of global risk aversion in explaining the spreads but do not find a significant role for the US Federal Funds rate. Among studies that focus on countryspecific factors, Jaramillo and Tejada (2011) find that, in addition to country fundamentals, credit ratings have a significant impact on spreads. Akitoby and Stratmann (2008) concentrate on fiscal variables, distinguishing between the effect on spreads of revenue- and tax-based fiscal adjustment, debt- and tax-financed current spending and considering the interaction between fiscal variables and political institutions. Baldacci et al. (2008) show that political risk factors, including expropriation risk, play a significant role in raising sovereign spreads, as investors demand an extra premium for political instability, even though fiscal variables are more important and have a larger impact on spreads.

Works that look at the interaction of country-specific and global factors and the evolution of their role, essentially find that: i) the sensitivity of spreads to country fundamentals depends on global liquidity and risk factors; ii) better fundamentals reduce the impact of global factors on spreads; iii) fundamentals matter most in the long-term, while global factors matter both in the 
short and long term.11

This paper considers both country-specific and global factors; in particular, drawing from Comelli (2012) and Csonto and Ivaschenko (2013), we exploit the ICRG database for country (economic, financial and political) fundamentals. As to the empirical strategy, we estimate a fixed effect panel model on the determinants of sovereign spreads (Comelli (2012), Csonto and Ivaschenko (2013), Akitoby and Stratmann (2008) and Jaramillo and Tejada (2011)).

Our original contribution is to assess the IMF's role in explaining emerging market spreads. In a similar vein, Lo Duca and Stracca (2014) run an event study to test the effect of G20 meetings at ministerial and Leaders level between 2007 and 2013 on global financial markets. Their main result is negative, suggesting the limited importance of G20 decisions from a market perspective.

\section{Data}

We consider 28 emerging market countries with monthly observations from October 1998 to July 2014 (178 periods). The dependent variable is, for each country, the monthly Emerging Market Bond Index Global (EMBIG) sovereign spreads provided by J. P. Morgan ${ }^{12}$ EMBIG tracks total returns for traded external debt instruments (external debt meaning foreign currency denominated fixed income instruments) issued by sovereign or quasi-sovereign entities of emerging market economies, and here we consider stripped spreads which show the yield differential in percentage points over US Treasuries, stripping out any credit enhancements such as principal and/or interest collateral 13

\footnotetext{
${ }^{11}$ For a more detailed discussion on this literature, see Csonto and Ivaschenko (2013).

${ }^{12}$ For Argentina, Brazil, Bulgaria, Chile, China, Colombia, Croatia, Cote d'Ivoire, Dominican Republic, Ecuador, Egypt, El Salvador, Hungary, Lebanon, Malaysia, Mexico, Morocco, Pakistan, Panama, Peru, Philippines, Poland, Russia, South Africa, Turkey, Ukraine, Uruguay and Venezuela, the dependent variable is available in at least half of the periods under observation. In general, not every variable is available for all countries or for the full time period.

${ }^{13}$ J.P. Morgan also provides another index of emerging market spread, EMBI+, which differs from EMBIG in the criteria used for including instruments in the calculation. Instruments in the EMBI+ must have a minimum face value outstanding of $\$ 500$ million
} 
We use as country-specific fundamentals the risk indicators of the International Country Risk Guide (ICRG) database, which contains monthly information on countries' economic, political and financial situation ${ }^{14}$ The composite risk ratings are calculated as the weighted average of the scores assigned to a number of risk subcomponents, as detailed below. The advantage of using ICRG data lies in the fact that they are available with monthly frequency and account for different aspects of the countries' situation that have all been found to be relevant in explaining spreads by the previous literature (namely economic, financial and political variables).

- The Economic Risk Rating (ERR) measures the soundness of the macroeconomic fundamentals and includes five components: per capita GDP, real GDP growth rate, inflation, and the fiscal and current account balances as a percentage of GDP. The ERR can take value between 0 and 50; low scores signal weak macroeconomic fundamentals, while high scores are associated with sound fundamentals.

- The Financial Risk Rating (FRR) values the ability of a country to pay its external debt obligations and is based on: external debt as a percentage of GDP, external debt as a percentage of exports of goods and services, current account balance as a percentage of exports of goods, the ratio of official reserves holdings to monthly imports, and a measure of nominal exchange rate stability. As the ERR, the FRR can take values between 0 and 50, with low values indicating a high degree of external vulnerability and high values indicating low vulnerability (or better resilience to external shocks).

- The Political Risk Rating (PRR) measures the degree of political stability in a given country. It is based on the following sub-

and must meet strict criteria for secondary market trading liquidity, while countries are selected according to a sovereign credit-rating level. EMBIG instead defines emerging markets countries with a combination of World Bank-defined per capita income brackets and each country's debt-restructuring history. These two criteria allow the EMBI Global to include a number of higher-rated countries. Also, EMBIG's secondary market liquidity constraints are more loose than for EMBI+, and allow the inclusion of nearly twice as many instruments. However, EMBI+ and EMBIG feature very similar patterns.

${ }^{14}$ The ICRG database is compiled by the PRS Group. A detailed description of the methodology is available at https://www.prsgroup.com/about-us/our-twomethodologies/icrg. 
components: government stability, socio-economic conditions, investment profile, internal and external conflict, corruption, military in power, religious tensions, law and order, ethnic tensions, democratic accountability and bureaucracy quality. The PRR ranges from 0 to 100, with low scores associated with high political risk.

Among the global factors affecting the spreads, we take into account global risk aversion and global liquidity conditions, again following Comelli (2012) and Csonto and Ivaschenko (2013) and the references therein. Global risk appetite is measured by the Chicago Board Options Exchange Volatility Index (VIX), which measures the implied volatility of S\&P index options and therefore is expected to be positively associated with the spreads. As a proxy for global liquidity conditions we use ten-year US interest rates.15

In addition to the variables mentioned above, which are commonly used in the literature, we add other variables to account for the role of the IMF. In particular, we consider the resources of the Fund available for crisis prevention and resolution upon request by a member country (Forward Commitment Capacity, $F C C$ ), the activation of a Flexible Credit Line $(F C L)$ or, as an alternative, each country's potential ability to access it in each period (FCLqual).

The FCC is a measure of the resources available for new financial commitments in the coming year, and takes into account the uncommitted usable resources (including those activated under the NAB), the expected disbursements and repayments, ${ }^{16}$

The FCL variable is a dummy taking value 1 for the three countries that have so far used the precautionary facility, namely Mexico (since April), Colombia and Poland (since May 2009) ${ }^{17}$

As regards FCL potential qualifiers, the IMF does not disclose any informa-

\footnotetext{
${ }^{15}$ As an alternative to this measure, in Table 8 we analyse the impact of other variables accounting for global liquidity conditions, namely the global 10-year interest rate, the short term US interest rate and the Federal Funds rate.

${ }^{16}$ We use the monthly data for FCC available on the IMF website starting from October 2002. From October 1998 to September 2002 we use net uncommitted usable resources as a proxy of the FCC. The relationship between the one-year Forward Commitment Capacity and usable resources is defined as follows: FCC $=$ usable resources - undrawn balances under General Resources Account (i.e. non- concessional) arrangements + repurchase one year forward - repayments of borrowing one year forward - prudential balance. In the definition of FCC, usable resources do not include the resources made available through the bilateral borrowing agreements if this second line of defence is not activated.

${ }^{17}$ We decided not to include a dummy variable for the other precautionary instrument
} 
tion on the availability of the precautionary instruments for its members, so as to avoid any undesirable market impact. In IMF (2010 and 2014) there is a reference to potential qualifiers "based on investment banks reports" or "identified by private sector analysts", but no additional information is given on which members are in the group, or on the methodology to identify them. Fernandez-Arias and Levy-Yeyati (2010) assume as potential qualifiers those countries having a sovereign spread below the highest spread among the countries that were explicitly granted an FCL (that is Colombia). Following and refining this approach, we define as potential qualifiers those countries that, starting from April 2009, were in a risk situation which was comparable with or better than that of the countries that had actually been granted an FCL ${ }^{18}$ In particular, a country is deemed eligible for the FCL if it meets the following conditions:

- ERR and FRR indexes greater than in the country with the best (highest) index among the three FCL countries at the time of approval;

- PRR index greater than in the country with the lowest index among the three FCL countries at the time of approval ${ }^{19}$.

- Currently not in an IMF financing program or precautionary program (Flexible Credit Line or Precautionary and Liquidity Line)

The final selection yields 546 country-month observations where the dummy equals one, comprising 13 countries ${ }^{20}$

Table 1 reports the descriptive statistics for the variables, while Table 3 contains their pairwise correlation matrix. Table 4 reports all the variables used in the regressions with their code, description and source.

To provide a first glance at the possible effects of the FCL, in Table 2 we show the mean values of the dependent variable and of the risk ratings by

(the Precautionary and Liquidity Line, formerly the Precautionary Credit Line) because of the very limited use countries made of such facility. Using a dummy variable taking into account both FCL and PLL/PCL at the same time does not yield different results with respect to the FCL dummy.

${ }^{18}$ We exclude the condition on EMBI spreads to avoid selection bias in the regressions.

${ }^{19}$ This is due to the fact that FCL qualification criteria mainly focus on economic and financial situation of the country; the political outlook is important but is not explicitly taken into account in the FCL conditionality (see footnote 6).

${ }^{20}$ Namely Brazil, Bulgaria, Chile, China, Dominican Republic, El Salvador, Malaysia, Panama, Peru, Philippines, Russia, South Africa, Uruguay. 
country group (namely FCL qualifiers, non-qualifiers and users); in addition, in Figure 2 we plot the ten-day moving average of daily EMBIG spreads for different groups of countries compared with the composite index (which includes all the countries for which EMBIG is available), taking as base date the last day of the London summit, i.e. April 7, 2009. As expected, the indexes for FCL users and qualifiers lie below the composite one.

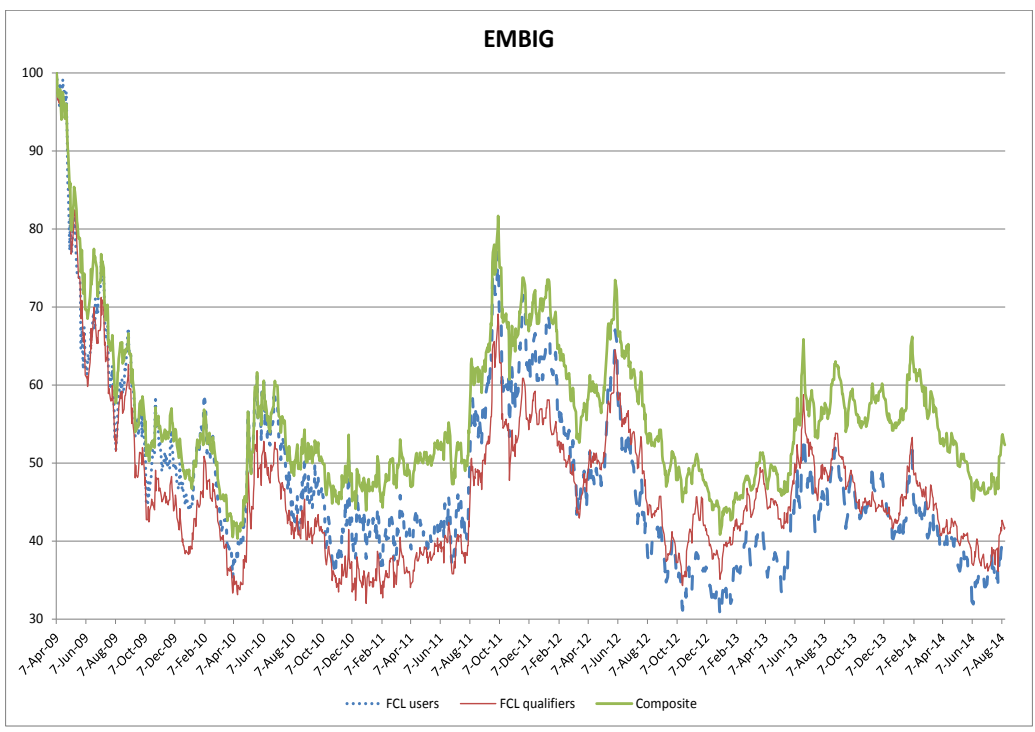

Figure 2: EMBIG spreads (ten-day moving average; index numbers, April 7, $2009=100)$

\section{Empirical model}

The empirical model used in this analysis exploits a simplified version of the model developed by Edwards (1984) and generally used in the literature.

For a risk-neutral investor lending to a given country which is a price-taker in the capital market the equilibrium condition of an optimal portfolio allocation is:

$$
\left(1+r^{*}\right)=\pi d+(1-\pi)\left(1+r^{*}+s\right)
$$


where $r^{*}$ is the international risk-free interest rate, $\pi$ is the probability of default of the borrowing country, $d$ is the payment the investor receives in case of default and $s$ is a spread for the country risk premium. From (1)

$$
s=\frac{\pi}{1-\pi}\left(1+r^{*}-d\right)
$$

i.e the country risk premium depends: positively, on the probability of default and the global risk-free interest rate and negatively, on the recovery payment. Assuming that the probability of default follows a logistic distribution:

$$
\pi=\frac{\exp \left(\sum_{i} \beta_{i} X_{i}\right)}{1+\exp \left(\sum_{i} \beta_{i} X_{i}\right)}
$$

the spread equation takes the following form

$$
\ln (s)=\ln \left(1+r^{*}-d\right)+\sum_{i} \beta_{i} X_{i}
$$

where $X_{i}$ and $\beta_{i}$ are the determinants of the probability of default and the corresponding coefficients. In our model $X_{i}$ includes the country-specific fundamentals, the global market conditions and the IMF-related variables. Following Comelli (2012), all variables are transformed into natural logs to smooth their profile and facilitate the interpretation of the coefficients, while the country risk ratings are lagged in order to control for endogeneity. As suggested by the Hausman test performed in each specification of the model, we use a fixed effects estimation with standard errors robust to disturbance being heteroskedastic and autocorrelated. ${ }^{21}$

\section{$6 \quad$ Estimation results}

The baseline regressions show that both the traditional country-specific and global explanatory variables are statistically significant in explaining emerging market bond spreads, in line with the literature. Columns (1) and (2) of Table 5 broadly replicate the results of Comelli (2012) and Csonto and Ivaschenko (2013) showing the significant negative impact of country fundamentals on spreads (the better the risk ratings, the lower the sovereign

\footnotetext{
${ }^{21}$ Jaramillo and Tejada (2011), Comelli (2012), and Csonto and Ivaschenko (2013) estimate fixed effects models with robust standard errors.
} 
spreads; a 10 percent increase in one of the indexes lowers the spreads by between 6 and 30 percent, depending on which index is considered) and the significant positive impact of the VIX (a 10 percent increase of the VIX raises emerging markets bond spreads by about 6 percent). A less clear-cut picture emerges on the role of the US long-term interest rate: its coefficient is significant and negative in two out of four specifications (columns (3) and (4)). This finding is consistent with Eichengreen and Mody (2000) and with the idea that when US interest rates fall there is a greater appetite for higheryielding emerging market bonds. Other studies have found mixed evidence: Gonzales-Rosada and Levy-Yeyati (2006), for example, find that the magnitude and sometimes the sign of the coefficient of global factors differ between investment-grade and speculative grade countries, and between distressed and tranquil times.22

The inclusion of the FCC variable shows that the size of the Fund has a significant negative impact on spreads in the two specifications where it is included. For example, from January 2009 to January 2010, the FCC increased from $\$ 95$ billion to $\$ 154$ billion and the EMBIG Composite index decreased from 655 points to 322 . On the basis of our estimated elasticity of -0.18 , the FCC increase explains about 21 percent of the EMBIG decrease recorded in that year.

Column (4) considers the interaction between the resource variable and a dummy indicating whether in the specified period the country is under a non-concessional program with the IMF. The positive and significant small coefficient may suggest that the effect of the FCC is lower for those countries already using IMF resources, since the FCC represents the potential endowment available for countries not yet under a program.

In Table 6 we focus on the effect of the FCL on spreads by considering an $F C L$ variable only for those countries that actually made use of the facility (Colombia, Mexico and Poland) and an FCL_qual dummy for the countries with potential access (according to the methodology explained in Section 4). None of them turn out to be significant (columns 2 and 3). Also the interaction between $F C L_{-} q u a l$ and FCC is not significant, while the FCC variable preserves its role (column 4).

\footnotetext{
${ }^{22}$ Our result does not change when using other measures of global liquidity. See the end of the paragraph.
} 
To address the issue of potential multicollinearity stemming from the fact that the FCL qualifiers are defined on the basis of the risk indexes used as independent variables, we compute the Variance Inflation Factor (VIF) of all the FCL-related variables, which is a gauge of the variance of a coefficient due to the (linear) dependence from other predictors. As a rule of thumb, a value of the VIF factor greater than 10 indicates strong multicollinearity, while values below 2.5 should not raise major concerns. The estimated factors (reported at the bottom of the regression tables) range from 1.09 to 1.90, thus excluding possible biases due to multicollinearity.

When we use dummy variables to check for specific event effects (Table 10), such as the global financial crisis (from August 2007, when BNP Paribas announced it was ceasing its activity in three hedge funds specialized in US mortgage debt, to December 2009) and the European crisis period (from May 2010, when the first IMF program was signed with Greece, to the end of the sample), the estimates show that the IMF preserved its role as safety net for emerging market countries.

All in all, our analysis shows that the resources made available by the IMF as a component of the GFSN have an impact on the perceived riskiness of emerging market countries, while the role of the precautionary instruments does not seem to be significant per se. In other terms, what seems to matter most is how much money is available for crisis prevention and resolution, rather than the channels through which such funds are made available.

Robustness checks As a robustness check, we use different measures of global liquidity instead of the US long-term interest rate, namely (i) a global long-term interest rate given by the average of the 10-year rates of the US, UK, Japan and Euro Area, (ii) the US three-month rate and (iii) the Federal Funds rate. Table 8 shows what happens using these metrics in the baseline regression. These alternative measures of global liquidity conditions (which are inserted in the model one at a time, given their high correlation) broadly confirm the baseline results obtained with the US 10-year interest rate: the coefficient of the different metrics of global liquidity conditions is negative and the significance of the FCC variable still holds across models.

To check the robustness of the results on the FCL, we use different eligibility criteria, based on several combinations of the criteria (see Table 9) and a more relaxed condition for applying countries(qualifiers are selected according to their index being better than the worst among the approved 
FCL countries, instead of better than the best; column G). In this way, the number of country-month observations selected falls from 4627 to 546 (in the original definition, which is the most restrictive one) or 923 (column C, which only takes into account the political risk index). Regressions based on alternative definitions confirm the baseline results: the eligibility to the FCL does not significantly affect the spreads (Tables 10 and 11 ).

\section{Conclusions}

The aim of this paper was to assess empirically the effectiveness of the IMF as a component of the Global Financial Safety Net, by running a panel regression on a sample of emerging market sovereign spreads. In particular, we assessed the confidence-building effect of a well-resourced IMF, by checking whether the variables related to the Fund's resources and facilities have a role in explaining those spreads, after controlling for the traditional determinants of the spreads identified by the literature.

Our results suggest that the size of Fund resources has a favourable effect on the risk outlook and borrowing costs of emerging market countries, regardless of the channels through which IMF resources can be accessed. This evidence is consistent with the notion that the IMF's lending capacity has a confidence-building effect. This finding underlines the importance of an adequately resourced IMF, a key issue in the context of the ongoing $15 \hat{t} h$ General Review of Quotas.

Our failure to find a statistically significant impact of the potential availability of the FCL on the EMBIG spread can be interpreted in several ways. First, the lack of transparency on the conditions for access to the facility may have played an important role. In other words, if financial markets do not receive clear signals from the Fund on whether a given country is eligible to get access to the FCL, they may prefer not to formulate a guess about its availability. Uncertainty about the size of the FCL access that an applicant country can obtain is a further element that weakens transparency. Second, the usual argument about the mispricing of extreme events by financial markets can be advocated: if a country has "very strong" fundamentals then the scenario where it ends up applying for the Fund's assistance has a very low probability of occurring. Finally, we cannot exclude that the criteria we proposed to identify the countries potentially eligible to access to the FCL 
differ from the criteria market analysts have in mind. Depending on how we interpret the lack of impact of the FCL on spreads, different implications may follow for the need to review the main features of FCL, for example whether it would be desirable to increase transparency and predictability of access in order to send a clearer signal to financial markets on the creditworthiness of potential FCL users.

The question addressed in the paper is important from a policy perspective: it can provide an empirical underpinning to the ongoing international debate on the strengthening of the role of the IMF and of the GFSN in general. Indeed the fact that the size of the IMF may affect the perceived creditworthiness of emerging market countries (and therefore their borrowing costs) may represent an argument in favour of at least keeping the IMF resources at their current level. On the other hand, the apparently weaker impact of the IMF facilities on the sovereign spreads may suggest that reforming the toolkit, without looking at the available resources, may not be the best way to ensure the effectiveness of the IMF as a component of the GFSN. Although this work only looks at the role of the IMF, its findings fit into the broader debate on the adequacy of the GFSN and the effectiveness of the International Monetary System. In particular, further research could shed light on broader issues such as the overall size of the Global Financial Safety Net and the role that Regional Financing Arrangements can play in it.

\section{References}

Akitoby, B. and Stratmann, T., 2008. "Fiscal policy and financial markets". The Economic Journal, volume 118(553): 1971-1985.

Baldacci, E., Gupta, S. and Mati, A., 2008. "Is it (still) mostly fiscal? Determinants of sovereign spreads in emerging markets". IMF Working Paper No. 08/259.

Comelli, F., 2012. "Emerging market sovereign bond spreads: Estimation and back-testing". Emerging Markets Review, volume 13(4): 598-625.

Csonto, B. and Ivaschenko, I., 2013. "Determinants of sovereign bond spreads in emerging markets: local fundamentalsand global factors vs. ever-changing misalignments". IMF Working Paper No. 164/2013. 
Denbee, E., Jung, C. and Paternó, F., 2016. "Stitching together the global financial safety net". Questioni di Economia e FInanza (Occasional Papers) No. 322, Bank of Italy.

Edwards, S., 1984. "LDC foreign borrowing and default risk: an empirical investigation, 1976-80". American Economic Review, volume 74(4): 726734 .

Eichengreen, B. and Mody, A., 2000. "What explains changing spreads on emerging market debt?" NBER Chapters, in: Capital Flows and the Emerging Economies: Theory, Evidence, and Controversies, pp. 107-136.

Fernandez-Arias, E. and Levy-Yeyati, E., 2010. "Global financial safety nets: where do we go from here?" Inter-American Development Bank Working Paper No. 231.

Gonzales-Rosada, B. and Levy-Yeyati, E., 2006. "Global factors and emerging markets spreads". Inter-American Development Bank Working Paper No. 552.

Hartelius, K. K., Kristian and Kodres, L. E., 2008. "Emerging market spread compression: is it real or is it liquidity?" IMF Working Paper No. $08 / 10$.

IMF, 2010. "The Fund's mandate. Future financing role". http://www. imf .org/external/np/pp/eng/2010/032510a.pdf.

IMF, 2014. "Review of the Flexible Credit Line, the Precautionary and Liquidity Line and the Rapid Financing Instrument". IMF Policy Paper.

Izquierdo, A. and Talvi, E., 2009. "A stability pact á la Maastricht for emerging markets". http://www.voxeu.org/index.php?q=node/4360

Jaramillo, L. and Tejada, C. M., 2011. "Sovereign credit ratings and spreads in emerging markets: does investment grade matter?" IMF Working Paper No. 11/44.

Levy-Yeyati, E. and Williams, T., 2010. "US rates and emerging markets spreads". Universidad Torcuato Di Tella, Business School Working Paper 02/2010. 
Lo Duca, M. and Stracca, L., 2014. "The effects of G20 Summits on global financial markets". ECB Working Paper No. 1668.

Luengnaruemitchai, P. and Schadler, S., 2007. "Do economists' and financial markets' perspectives in the new members of EU differ?" IMF Working Paper No. 65/200\%.

Peiris, S., 2010. "Foreign participation in emerging markets local currency bond markets". IMF Working Paper No. 88/2010.

Truman, E., 2013. "Enhancing the global financial safety net through central-bank cooperation". http://www.voxeu.org/article/enhancingglobal-financial-safety-net-through-central-bank-cooperation. 


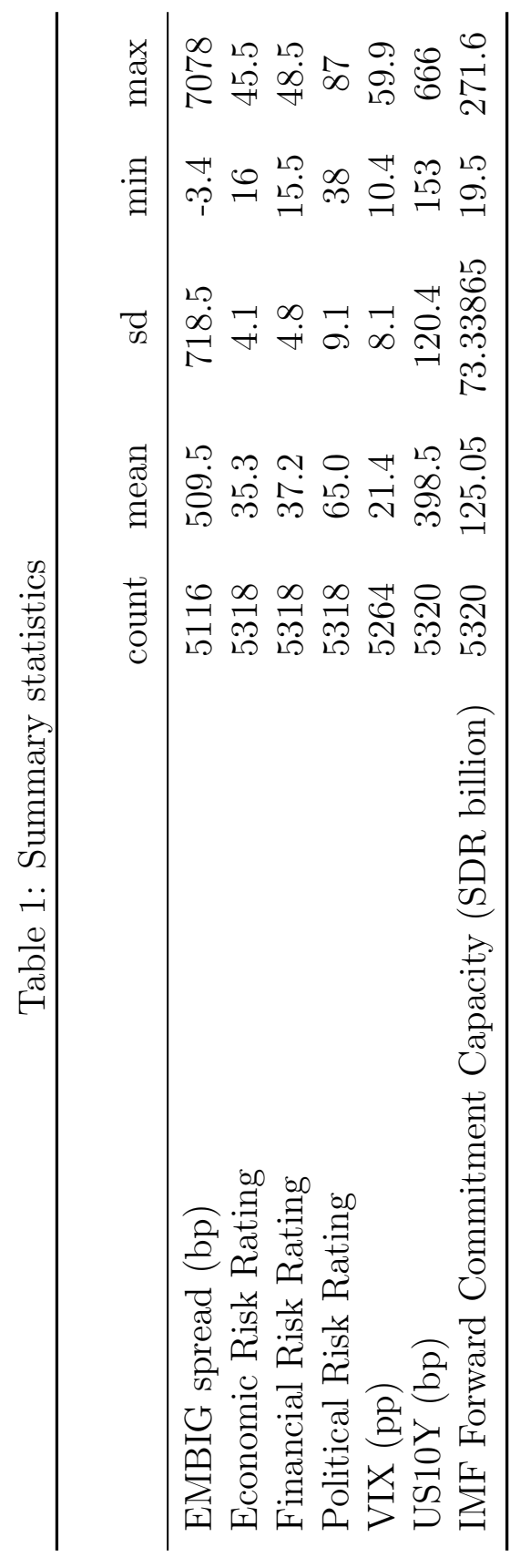


Table 2: Mean values by group of countries (Whole sample)

\begin{tabular}{ccccc}
\hline Variable & All countries & FCL users & FCL qualifiers & FCL non-qualifiers \\
\hline EMBI & 522.9 & 181.2 & 179.2 & 554.5 \\
ERR & 35.1 & 35.8 & 38.2 & 34.8 \\
FRR & 36.9 & 39.1 & 41.8 & 36.5 \\
PRR & 65.4 & 68.8 & 67.4 & 65.2 \\
\hline
\end{tabular}

Table 3: Pairwise correlations

\begin{tabular}{|c|c|c|c|c|c|c|c|}
\hline & $\operatorname{lnEMBI}$ & laglnERR & laglnFRR & laglnPRR & $\operatorname{lnVIX}$ & $\operatorname{lnUS10Y}$ & $\operatorname{lnFCC}$ \\
\hline $\operatorname{lnEMBI}$ & 1.000 & & & & & & \\
\hline laglnERR & $\begin{array}{c}-0.390^{* * *} \\
(0.000)\end{array}$ & 1.000 & & & & & \\
\hline laglnFRR & $\begin{array}{c}-0.496^{* * *} \\
(0.000)\end{array}$ & $\begin{array}{c}0.541^{* * *} \\
(0.000)\end{array}$ & 1.000 & & & & \\
\hline laglnPRR & $\begin{array}{c}-0.557^{* * *} \\
(0.000)\end{array}$ & $\begin{array}{c}0.353^{* * *} \\
(0.000)\end{array}$ & $\begin{array}{c}0.080^{* * *} \\
(0.000)\end{array}$ & 1.000 & & & \\
\hline $\operatorname{lnVIX}$ & $\begin{array}{c}0.311^{* * *} \\
(0.000)\end{array}$ & $\begin{array}{c}-0.134^{* * *} \\
(0.000)\end{array}$ & $\begin{array}{c}-0.157^{* * *} \\
(0.000)\end{array}$ & $\begin{array}{l}-0.000 \\
(0.983)\end{array}$ & 1.000 & & \\
\hline $\operatorname{lnUS10Y}$ & $\begin{array}{c}0.052^{* * *} \\
(0.000)\end{array}$ & $\begin{array}{l}-0.036^{*} \\
(0.011)\end{array}$ & $\begin{array}{c}-0.217^{* * *} \\
(0.000)\end{array}$ & $\begin{array}{c}0.104^{* * *} \\
(0.000)\end{array}$ & $\begin{array}{c}0.020 \\
(0.150)\end{array}$ & 1.000 & \\
\hline $\operatorname{lnFCC}$ & $\begin{array}{c}-0.193^{* * *} \\
(0.000)\end{array}$ & $\begin{array}{c}0.110^{* * *} \\
(0.000)\end{array}$ & $\begin{array}{c}0.292^{* * *} \\
(0.000)\end{array}$ & $\begin{array}{c}-0.104^{* * *} \\
(0.000)\end{array}$ & $\begin{array}{c}-0.263^{* * *} \\
(0.000)\end{array}$ & $\begin{array}{c}-0.720^{* * *} \\
(0.000)\end{array}$ & 1.000 \\
\hline
\end{tabular}




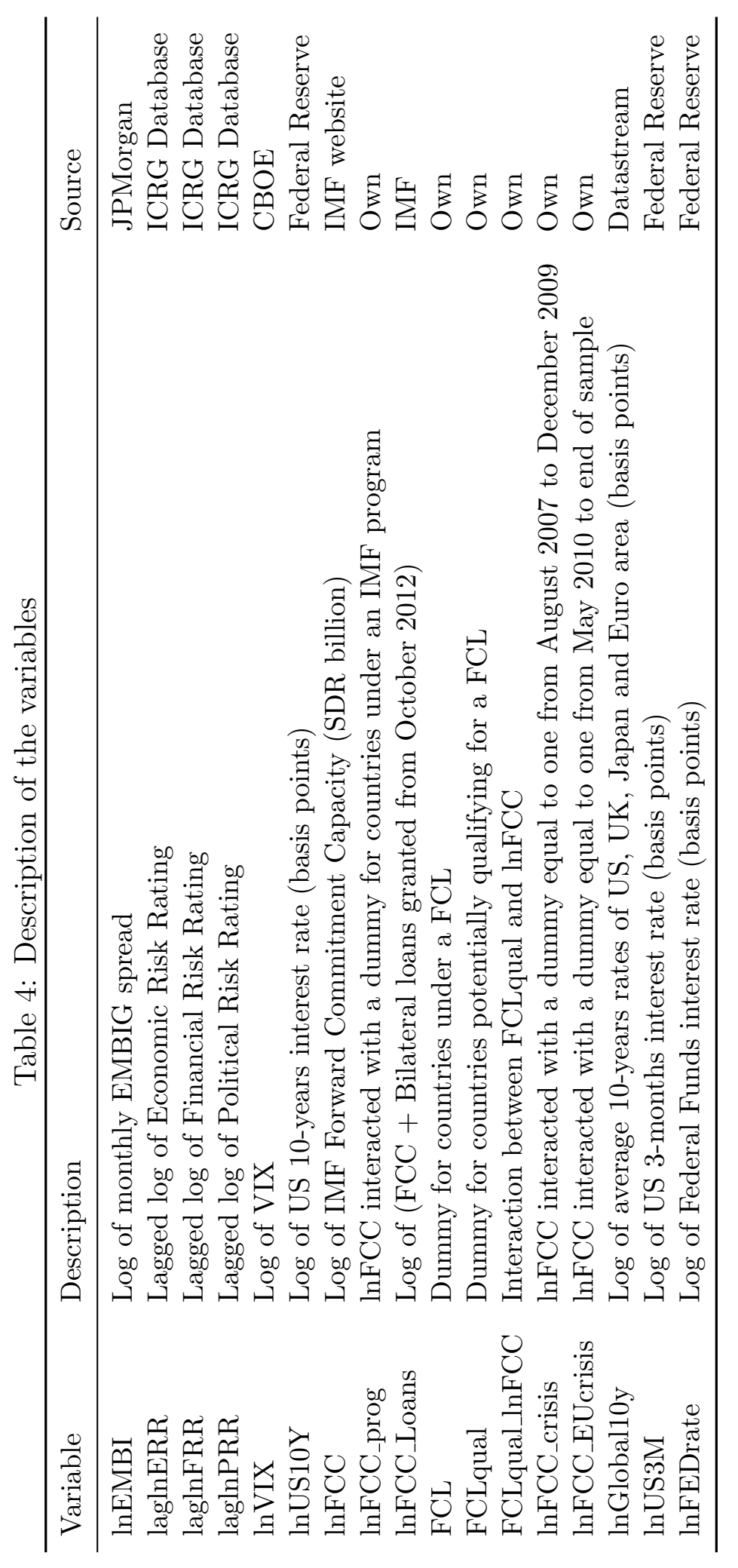


Table 5: EMBIG spreads and FCC

\begin{tabular}{|c|c|c|c|c|}
\hline & $\begin{array}{c}(1) \\
\operatorname{lnEMBI}\end{array}$ & $\begin{array}{c}(2) \\
\ln E M B I\end{array}$ & $\begin{array}{c}(3) \\
\ln \mathrm{EMBI}\end{array}$ & $\begin{array}{c}(4) \\
\ln \mathrm{EMBI}\end{array}$ \\
\hline laglnERR & $\begin{array}{c}-0.839^{* * *} \\
(0.292)\end{array}$ & $\begin{array}{c}-0.634^{* *} \\
(0.255)\end{array}$ & $\begin{array}{c}-0.604^{* *} \\
(0.251)\end{array}$ & $\begin{array}{c}-0.600^{* *} \\
(0.247)\end{array}$ \\
\hline laglnFRR & $\begin{array}{c}-2.988^{* * *} \\
(0.351)\end{array}$ & $\begin{array}{c}-2.590^{* * *} \\
(0.333)\end{array}$ & $\begin{array}{c}-2.437^{* * *} \\
(0.357)\end{array}$ & $\begin{array}{c}-2.378^{* * *} \\
(0.348)\end{array}$ \\
\hline laglnPRR & $\begin{array}{c}-2.653^{* * *} \\
(0.539)\end{array}$ & $\begin{array}{c}-2.779^{* * *} \\
(0.499)\end{array}$ & $\begin{array}{c}-2.931^{* * *} \\
(0.487)\end{array}$ & $\begin{array}{c}-2.916^{* * *} \\
(0.476)\end{array}$ \\
\hline $\operatorname{lnVIX}$ & & $\begin{array}{l}0.629^{* * *} \\
(0.0684)\end{array}$ & $\begin{array}{c}0.568^{* * *} \\
(0.0716)\end{array}$ & $\begin{array}{l}0.569^{* * *} \\
(0.0716)\end{array}$ \\
\hline $\operatorname{lnUS10Y}$ & & $\begin{array}{l}0.0316 \\
(0.108)\end{array}$ & $\begin{array}{c}-0.168^{* *} \\
(0.0736)\end{array}$ & $\begin{array}{c}-0.167^{* *} \\
(0.0727)\end{array}$ \\
\hline $\operatorname{lnFCC}$ & & & $\begin{array}{l}-0.183^{* *} \\
(0.0757)\end{array}$ & $\begin{array}{l}-0.177^{* *} \\
(0.0750)\end{array}$ \\
\hline lnFCC_prog & & & & $\begin{array}{l}0.0290^{*} \\
(0.0149)\end{array}$ \\
\hline _cons & $\begin{array}{c}30.55^{* * *} \\
(2.306)\end{array}$ & $\begin{array}{c}26.98^{* * *} \\
(2.461)\end{array}$ & $\begin{array}{c}28.26^{* * *} \\
(2.295)\end{array}$ & $\begin{array}{c}27.92^{* * *} \\
(2.285)\end{array}$ \\
\hline $\begin{array}{l}\text { adj. } R^{2} \\
N\end{array}$ & $\begin{array}{c}0.401 \\
4683\end{array}$ & $\begin{array}{c}0.511 \\
4627\end{array}$ & $\begin{array}{c}0.521 \\
4627\end{array}$ & $\begin{array}{l}0.525 \\
4627\end{array}$ \\
\hline
\end{tabular}

Fixed-effect regression. Standard errors in parentheses.

${ }^{*} p$-value $<0.1,{ }^{* *} p$-value $<0.05,{ }^{* * *} p$-value $<0.01$

Dependent variable: log of monthly EMBIG spread.

For a description of the variables, see Table 4 . 
Table 6: EMBIG spreads and FCL

\begin{tabular}{|c|c|c|c|c|}
\hline & $\begin{array}{c}(1) \\
\ln \mathrm{EMBI}\end{array}$ & $\begin{array}{c}(2) \\
\ln \mathrm{EMBI}\end{array}$ & $\begin{array}{c}(3) \\
\ln \mathrm{EMBI}\end{array}$ & $\begin{array}{c}(4) \\
\ln \mathrm{EMBI}\end{array}$ \\
\hline $\operatorname{lag} \ln E R R$ & $\begin{array}{c}-0.604^{* *} \\
(0.251)\end{array}$ & $\begin{array}{c}-0.638^{* *} \\
(0.255)\end{array}$ & $\begin{array}{c}-0.656^{* *} \\
(0.265)\end{array}$ & $\begin{array}{c}-0.620^{* *} \\
(0.258)\end{array}$ \\
\hline laglnFRR & $\begin{array}{c}-2.437^{* * *} \\
(0.357)\end{array}$ & $\begin{array}{c}-2.592^{* * *} \\
(0.332)\end{array}$ & $\begin{array}{c}-2.517^{* * *} \\
(0.339)\end{array}$ & $\begin{array}{c}-2.396^{* * *} \\
(0.350)\end{array}$ \\
\hline laglnPRR & $\begin{array}{c}-2.931^{* * *} \\
(0.487)\end{array}$ & $\begin{array}{c}-2.760^{* * *} \\
(0.496)\end{array}$ & $\begin{array}{c}-2.779^{* * *} \\
(0.497)\end{array}$ & $\begin{array}{c}-2.919^{* * *} \\
(0.488)\end{array}$ \\
\hline $\ln$ VIX & $\begin{array}{l}0.568^{* * *} \\
(0.0716)\end{array}$ & $\begin{array}{l}0.629^{* * *} \\
(0.0687)\end{array}$ & $\begin{array}{c}0.628^{* * *} \\
(0.0674)\end{array}$ & $\begin{array}{c}0.569^{* * *} \\
(0.0714)\end{array}$ \\
\hline $\operatorname{lnUS10Y}$ & $\begin{array}{l}-0.168^{* *} \\
(0.0736)\end{array}$ & $\begin{array}{l}0.0239 \\
(0.117)\end{array}$ & $\begin{array}{c}-0.00758 \\
(0.118)\end{array}$ & $\begin{array}{l}-0.193^{* *} \\
(0.0820)\end{array}$ \\
\hline $\operatorname{lnFCC}$ & $\begin{array}{l}-0.183^{* *} \\
(0.0757)\end{array}$ & & & $\begin{array}{l}-0.171^{* *} \\
(0.0774)\end{array}$ \\
\hline FCL & & $\begin{array}{r}-0.0558 \\
(0.110)\end{array}$ & & \\
\hline FCLqual & & & $\begin{array}{c}-0.111 \\
(0.0905)\end{array}$ & \\
\hline FCLqual_lnFCC & & & & $\begin{array}{c}-0.0212 \\
(0.0190)\end{array}$ \\
\hline _cons & $\begin{array}{c}28.26^{* * *} \\
(2.295)\end{array}$ & $\begin{array}{c}26.94^{* * *} \\
(2.441)\end{array}$ & $\begin{array}{c}26.86^{* * *} \\
(2.462)\end{array}$ & $\begin{array}{c}28.11^{* * *} \\
(2.297)\end{array}$ \\
\hline adj. $R^{2}$ & 0.521 & 0.511 & 0.513 & 0.523 \\
\hline VIF & & 1.091 & 1.348 & 1.293 \\
\hline$N$ & 4627 & 4627 & 4627 & 4627 \\
\hline
\end{tabular}

Fixed-effect regression. Standard errors in parentheses.

${ }^{*} p$-value $<0.1,{ }^{* *} p$-value $<0.05,{ }^{* * *} p$-value $<0.01$

Dependent variable: $\log$ of monthly EMBIG spread.

For a description of the variables, see Table 4. 
Table 7: EMBIG spreads and FCC, specific events

\begin{tabular}{lccc}
\hline & $(1)$ & $(2)$ & $(3)$ \\
& $\operatorname{lnEMBI}$ & $\ln E M B I$ & $\ln E M B I$ \\
\hline laglnERR & $-0.604^{* *}$ & $-0.507^{* *}$ & $-0.516^{* *}$ \\
& $(0.251)$ & $(0.234)$ & $(0.238)$ \\
laglnFRR & $-2.437^{* * *}$ & $-2.362^{* * *}$ & $-2.421^{* * *}$ \\
& $(0.357)$ & $(0.362)$ & $(0.353)$ \\
laglnPRR & $-2.931^{* * *}$ & $-2.860^{* * *}$ & $-2.836^{* * *}$ \\
& $(0.487)$ & $(0.502)$ & $(0.509)$ \\
lnVIX & $0.568^{* * *}$ & $0.699^{* * *}$ & $0.590^{* * *}$ \\
& $(0.0716)$ & $(0.0837)$ & $(0.0755)$ \\
lnUS10Y & $-0.168^{* *}$ & -0.0743 & 0.0765 \\
& $(0.0736)$ & $(0.0799)$ & $(0.114)$ \\
lnFCC & $-0.183^{* *}$ & -0.119 & $-0.295^{* * *}$ \\
& $(0.0757)$ & $(0.0754)$ & $(0.0809)$ \\
lnFCC_crisis & & $-0.0557^{* * *}$ & \\
& & $(0.0143)$ & \\
lnFCC_EUcrisis & & & $0.0654^{* * *}$ \\
& & & $(0.0221)$ \\
_cons & $29.03^{* * *}$ & $26.93^{* * *}$ & $27.18^{* * *}$ \\
& $(2.355)$ & $(2.519)$ & $(2.538)$ \\
\hline adj. $R^{2}$ & 0.521 & 0.543 & 0.535 \\
$N$ & 4627 & 4627 & 4627 \\
\hline
\end{tabular}

Fixed-effect regression. Standard errors in parentheses.

${ }^{*} p$-value $<0.1,{ }^{* *} p$-value $<0.05,{ }^{* * *} p$-value $<0.01$

Dependent variable: log of monthly EMBIG spread.

For a description of the variables, see Table 4 . 
Table 8: EMBIG spreads and FCC. Robustness, different measures of global liquidity

\begin{tabular}{|c|c|c|c|c|}
\hline & $\begin{array}{c}(1) \\
\ln E M B I\end{array}$ & $\begin{array}{c}(2) \\
\ln \mathrm{EMBI}\end{array}$ & $\begin{array}{c}(3) \\
\ln E M B I\end{array}$ & $\begin{array}{c}(4) \\
\ln E M B I\end{array}$ \\
\hline laglnERR & $\begin{array}{c}-0.604^{* *} \\
(0.251)\end{array}$ & $\begin{array}{c}-0.557^{* *} \\
(0.250)\end{array}$ & $\begin{array}{l}-0.521^{*} \\
(0.255)\end{array}$ & $\begin{array}{c}-0.539^{* *} \\
(0.256)\end{array}$ \\
\hline laglnFRR & $\begin{array}{c}-2.437^{* * *} \\
(0.357)\end{array}$ & $\begin{array}{c}-2.445^{* * *} \\
(0.353)\end{array}$ & $\begin{array}{c}-2.468^{* * *} \\
(0.364)\end{array}$ & $\begin{array}{c}-2.458^{* * *} \\
(0.365)\end{array}$ \\
\hline laglnPRR & $\begin{array}{c}-2.931^{* * *} \\
(0.487)\end{array}$ & $\begin{array}{c}-2.893^{* * *} \\
(0.493)\end{array}$ & $\begin{array}{c}-2.930^{* * *} \\
(0.490)\end{array}$ & $\begin{array}{c}-2.937^{* * *} \\
(0.489)\end{array}$ \\
\hline $\operatorname{lnVIX}$ & $\begin{array}{c}0.568^{* * *} \\
(0.0716)\end{array}$ & $\begin{array}{l}0.579^{* * *} \\
(0.0705)\end{array}$ & $\begin{array}{l}0.548^{* * *} \\
(0.0732)\end{array}$ & $\begin{array}{l}0.564^{* * *} \\
(0.0728)\end{array}$ \\
\hline $\ln F C C$ & $\begin{array}{l}-0.183^{* *} \\
(0.0757)\end{array}$ & $\begin{array}{c}-0.231^{* * *} \\
(0.0771)\end{array}$ & $\begin{array}{l}-0.190^{* *} \\
(0.0785)\end{array}$ & $\begin{array}{c}-0.166^{* *} \\
(0.0778)\end{array}$ \\
\hline $\operatorname{lnUS10Y}$ & $\begin{array}{l}-0.168^{* *} \\
(0.0736)\end{array}$ & & & \\
\hline lnGlobal10Y & & $\begin{array}{c}-0.276^{* * *} \\
(0.0727)\end{array}$ & & \\
\hline $\operatorname{lnUS3M}$ & & & $\begin{array}{c}-0.0341^{* *} \\
(0.0140)\end{array}$ & \\
\hline lnFEDrate & & & & $\begin{array}{c}-0.0303^{*} \\
(0.0160)\end{array}$ \\
\hline _cons & $\begin{array}{c}29.03^{* * *} \\
(2.355)\end{array}$ & $\begin{array}{c}29.52^{* * *} \\
(2.309)\end{array}$ & $\begin{array}{c}28.09^{* * *} \\
(2.311)\end{array}$ & $\begin{array}{c}27.97^{* * *} \\
(2.302)\end{array}$ \\
\hline $\begin{array}{l}\text { adj. } R^{2} \\
N\end{array}$ & $\begin{array}{l}0.521 \\
4627\end{array}$ & $\begin{array}{c}0.526 \\
4627\end{array}$ & $\begin{array}{l}0.522 \\
4627\end{array}$ & $\begin{array}{l}0.520 \\
4627\end{array}$ \\
\hline
\end{tabular}

Fixed-effect regression. Standard errors in parentheses.

${ }^{*} p$-value $<0.1,{ }^{* *} p$-value $<0.05,{ }^{* * *} p$-value $<0.01$

Dependent variable: $\log$ of monthly EMBIG spread.

For a description of the variables, see Table 4 . 
Table 9: Different definitions of FCL qualifiers

\begin{tabular}{ccccccccc}
\hline Variable & Original def. & $\mathrm{A}$ & $\mathrm{B}$ & $\mathrm{C}$ & $\mathrm{D}$ & $\mathrm{E}$ & $\mathrm{F}$ & $\mathrm{G}$ \\
\hline ERR & $\mathrm{x}$ & $\mathrm{x}$ & & & $\mathrm{x}$ & & $\mathrm{x}$ & $x^{1}$ \\
FRR & $\mathrm{x}$ & & $\mathrm{x}$ & & $\mathrm{x}$ & $\mathrm{x}$ & & $x^{1}$ \\
PRR & $\mathrm{x}$ & & & $\mathrm{x}$ & & $\mathrm{x}$ & $\mathrm{x}$ & $\mathrm{x}$ \\
obs & 546 & 800 & 903 & 923 & 646 & 676 & 645 & 818 \\
\hline
\end{tabular}

1: Selection takes countries with indexes better than the worst among the approved FCL countries, instead of better than the best 
Table 10: EMBIG spreads and FCL. Robustness, different definitions of FCL qualifiers

\begin{tabular}{|c|c|c|c|c|c|c|c|c|}
\hline & $\begin{array}{c}(1) \\
\operatorname{lnEMBI}\end{array}$ & $\begin{array}{c}(2) \\
\operatorname{lnEMBI}\end{array}$ & $\begin{array}{c}(3) \\
\operatorname{lnEMBI}\end{array}$ & $\begin{array}{c}(4) \\
\ln E M B I\end{array}$ & $\begin{array}{c}(5) \\
\operatorname{lnEMBI}\end{array}$ & $\begin{array}{c}(6) \\
\operatorname{lnEMBI}\end{array}$ & $\begin{array}{c}(7) \\
\ln \mathrm{EMBI}\end{array}$ & $\begin{array}{c}(8) \\
\ln E M B I\end{array}$ \\
\hline laglnERR & $\begin{array}{c}-0.621^{* *} \\
(0.261)\end{array}$ & $\begin{array}{c}-0.600^{* *} \\
(0.247)\end{array}$ & $\begin{array}{c}-0.564^{*} \\
(0.299)\end{array}$ & $\begin{array}{l}-0.591^{*} \\
(0.309)\end{array}$ & $\begin{array}{c}-0.619^{* *} \\
(0.260)\end{array}$ & $\begin{array}{c}-0.650^{* *} \\
(0.287)\end{array}$ & $\begin{array}{c}-0.609^{* *} \\
(0.260)\end{array}$ & $\begin{array}{c}-0.582^{* *} \\
(0.279)\end{array}$ \\
\hline laglnFRR & $\begin{array}{c}-2.393^{* * *} \\
(0.356)\end{array}$ & $\begin{array}{c}-2.414^{* * *} \\
(0.369)\end{array}$ & $\begin{array}{c}-2.483^{* * *} \\
(0.366)\end{array}$ & $\begin{array}{c}-2.442^{* * *} \\
(0.372)\end{array}$ & $\begin{array}{c}-2.383^{* * *} \\
(0.353)\end{array}$ & $\begin{array}{c}-2.383^{* * *} \\
(0.361)\end{array}$ & $\begin{array}{c}-2.423^{* * *} \\
(0.371)\end{array}$ & $\begin{array}{c}-2.449^{* * *} \\
(0.368)\end{array}$ \\
\hline laglnPRR & $\begin{array}{c}-2.924^{* * *} \\
(0.488)\end{array}$ & $\begin{array}{c}-2.942^{* * *} \\
(0.480)\end{array}$ & $\begin{array}{c}-2.921^{* * *} \\
(0.488)\end{array}$ & $\begin{array}{c}-2.938^{* * *} \\
(0.505)\end{array}$ & $\begin{array}{c}-2.935^{* * *} \\
(0.485)\end{array}$ & $\begin{array}{c}-2.912^{* * *} \\
(0.492)\end{array}$ & $\begin{array}{c}-2.929^{* * *} \\
(0.489)\end{array}$ & $\begin{array}{c}-2.944^{* * *} \\
(0.500)\end{array}$ \\
\hline $\operatorname{lnVIX}$ & $\begin{array}{c}0.570^{* * *} \\
(0.0720)\end{array}$ & $\begin{array}{l}0.570^{* * *} \\
(0.0716)\end{array}$ & $\begin{array}{c}0.568^{* * *} \\
(0.0719)\end{array}$ & $\begin{array}{l}0.568^{* * *} \\
(0.0727)\end{array}$ & $\begin{array}{l}0.569^{* * *} \\
(0.0716)\end{array}$ & $\begin{array}{l}0.570^{* * *} \\
(0.0725)\end{array}$ & $\begin{array}{c}0.569^{* * *} \\
(0.0721)\end{array}$ & $\begin{array}{c}0.568^{* * *} \\
(0.0722)\end{array}$ \\
\hline $\operatorname{lnUS10Y}$ & $\begin{array}{c}-0.187^{* *} \\
(0.0806)\end{array}$ & $\begin{array}{c}-0.184^{* *} \\
(0.0818)\end{array}$ & $\begin{array}{l}-0.153^{*} \\
(0.0865)\end{array}$ & $\begin{array}{c}-0.161 \\
(0.0950)\end{array}$ & $\begin{array}{c}-0.190^{* *} \\
(0.0824)\end{array}$ & $\begin{array}{c}-0.190^{* *} \\
(0.0861)\end{array}$ & $\begin{array}{c}-0.178^{* *} \\
(0.0805)\end{array}$ & $\begin{array}{c}-0.150 \\
(0.0916)\end{array}$ \\
\hline $\operatorname{lnFCC}$ & $\begin{array}{c}-0.175^{* *} \\
(0.0785)\end{array}$ & $\begin{array}{c}-0.176^{* *} \\
(0.0772)\end{array}$ & $\begin{array}{c}-0.188^{* *} \\
(0.0832)\end{array}$ & $\begin{array}{c}-0.186^{* *} \\
(0.0767)\end{array}$ & $\begin{array}{c}-0.175^{* *} \\
(0.0793)\end{array}$ & $\begin{array}{c}-0.174^{* *} \\
(0.0804)\end{array}$ & $\begin{array}{c}-0.178^{* *} \\
(0.0759)\end{array}$ & $\begin{array}{c}-0.191^{* *} \\
(0.0758)\end{array}$ \\
\hline FCLqual & $\begin{array}{l}-0.0765 \\
(0.0950)\end{array}$ & & & & & & & \\
\hline FCLqual_A & & $\begin{array}{l}-0.0435 \\
(0.0742)\end{array}$ & & & & & & \\
\hline FCLqual_B & & & $\begin{array}{l}0.0396 \\
(0.102)\end{array}$ & & & & & \\
\hline FCLqual_C & & & & $\begin{array}{l}0.0174 \\
(0.113)\end{array}$ & & & & \\
\hline FCLqual_D & & & & & $\begin{array}{l}-0.0726 \\
(0.0895)\end{array}$ & & & \\
\hline FCLqual_E & & & & & & $\begin{array}{r}-0.0740 \\
(0.108)\end{array}$ & & \\
\hline FCLqual_F & & & & & & & $\begin{array}{c}-0.0339 \\
(0.0887)\end{array}$ & \\
\hline FCLqual_G & & & & & & & & $\begin{array}{c}0.0467 \\
(0.0978)\end{array}$ \\
\hline _cons & $\begin{array}{c}28.98^{* * *} \\
(2.353)\end{array}$ & $\begin{array}{c}29.05^{* * *} \\
(2.349)\end{array}$ & $\begin{array}{c}28.95^{* * *} \\
(2.387)\end{array}$ & $\begin{array}{c}29.00^{* * *} \\
(2.314)\end{array}$ & $\begin{array}{c}29.01^{* * *} \\
(2.344)\end{array}$ & $\begin{array}{c}29.02^{* * *} \\
(2.349)\end{array}$ & $\begin{array}{c}29.03^{* * *} \\
(2.354)\end{array}$ & $\begin{array}{c}28.98^{* * *} \\
(2.324)\end{array}$ \\
\hline adj. $R^{2}$ & 0.522 & 0.521 & 0.521 & 0.521 & 0.522 & 0.522 & 0.521 & 0.521 \\
\hline VIF & 1.348 & 1.576 & 1.865 & 1.585 & 1.496 & 1.447 & 1.379 & 1.542 \\
\hline$N$ & 4627 & 4627 & 4627 & 4627 & 4627 & 4627 & 4627 & 4627 \\
\hline
\end{tabular}

Fixed-effect regression. Standard errors in parentheses.

${ }^{*} p$-value $<0.1,{ }^{* *} p$-value $<0.05,{ }^{* * *} p$-value $<0.01$

Dependent variable: log of monthly EMBIG spread.

For a description of the variables, see Table 4. 
Table 11: EMBIG spreads and FCL. Robustness, different definitions of FCL qualifiers

\begin{tabular}{|c|c|c|c|c|c|c|c|c|}
\hline & $\begin{array}{c}(1) \\
\operatorname{lnEMBI}\end{array}$ & $\begin{array}{c}(2) \\
\ln \mathrm{EMBI}\end{array}$ & $\begin{array}{c}(3) \\
\ln E M B I\end{array}$ & $\begin{array}{c}(4) \\
\operatorname{lnEMBI}\end{array}$ & $\begin{array}{c}(5) \\
\ln \mathrm{EMBI}\end{array}$ & $\begin{array}{c}(6) \\
\operatorname{lnEMBI}\end{array}$ & $\begin{array}{c}(7) \\
\operatorname{lnEMBI}\end{array}$ & $\begin{array}{c}(8) \\
\ln E M B I\end{array}$ \\
\hline laglnERR & $\begin{array}{c}-0.620^{* *} \\
(0.258)\end{array}$ & $\begin{array}{c}-0.601^{* *} \\
(0.247)\end{array}$ & $\begin{array}{l}-0.547^{*} \\
(0.296)\end{array}$ & $\begin{array}{l}-0.570^{*} \\
(0.309)\end{array}$ & $\begin{array}{c}-0.617^{* *} \\
(0.260)\end{array}$ & $\begin{array}{c}-0.640^{* *} \\
(0.286)\end{array}$ & $\begin{array}{c}-0.606^{* *} \\
(0.259)\end{array}$ & $\begin{array}{l}-0.572^{*} \\
(0.279)\end{array}$ \\
\hline laglnFRR & $\begin{array}{c}-2.396^{* * *} \\
(0.350)\end{array}$ & $\begin{array}{c}-2.424^{* * *} \\
(0.368)\end{array}$ & $\begin{array}{c}-2.502^{* * *} \\
(0.364)\end{array}$ & $\begin{array}{c}-2.448^{* * *} \\
(0.369)\end{array}$ & $\begin{array}{c}-2.391^{* * *} \\
(0.352)\end{array}$ & $\begin{array}{c}-2.396^{* * *} \\
(0.360)\end{array}$ & $\begin{array}{c}-2.431^{* * *} \\
(0.371)\end{array}$ & $\begin{array}{c}-2.452^{* * *} \\
(0.365)\end{array}$ \\
\hline laglnPRR & $\begin{array}{c}-2.919^{* * *} \\
(0.488)\end{array}$ & $\begin{array}{c}-2.938^{* * *} \\
(0.481)\end{array}$ & $\begin{array}{c}-2.915^{* * *} \\
(0.488)\end{array}$ & $\begin{array}{c}-2.949^{* * *} \\
(0.506)\end{array}$ & $\begin{array}{c}-2.935^{* * *} \\
(0.485)\end{array}$ & $\begin{array}{c}-2.916^{* * *} \\
(0.492)\end{array}$ & $\begin{array}{c}-2.930^{* * *} \\
(0.489)\end{array}$ & $\begin{array}{c}-2.952^{* * *} \\
(0.500)\end{array}$ \\
\hline $\ln$ VIX & $\begin{array}{c}0.569^{* * *} \\
(0.0714)\end{array}$ & $\begin{array}{l}0.569^{* * *} \\
(0.0717)\end{array}$ & $\begin{array}{c}0.568^{* * *} \\
(0.0716)\end{array}$ & $\begin{array}{c}0.568^{* * *} \\
(0.0722)\end{array}$ & $\begin{array}{l}0.568^{* * *} \\
(0.0714)\end{array}$ & $\begin{array}{c}0.569^{* * *} \\
(0.0721)\end{array}$ & $\begin{array}{l}0.569^{* * *} \\
(0.0721)\end{array}$ & $\begin{array}{c}0.568^{* * *} \\
(0.0719)\end{array}$ \\
\hline $\operatorname{lnUS10Y}$ & $\begin{array}{c}-0.193^{* *} \\
(0.0820)\end{array}$ & $\begin{array}{l}-0.178^{* *} \\
(0.0823)\end{array}$ & $\begin{array}{c}-0.146 \\
(0.0872)\end{array}$ & $\begin{array}{c}-0.149 \\
(0.0964)\end{array}$ & $\begin{array}{l}-0.188^{* *} \\
(0.0829)\end{array}$ & $\begin{array}{c}-0.186^{* *} \\
(0.0866)\end{array}$ & $\begin{array}{c}-0.173^{* *} \\
(0.0808)\end{array}$ & $\begin{array}{c}-0.140 \\
(0.0923)\end{array}$ \\
\hline $\operatorname{lnFCC}$ & $\begin{array}{l}-0.171^{* *} \\
(0.0774)\end{array}$ & $\begin{array}{l}-0.178^{* *} \\
(0.0777)\end{array}$ & $\begin{array}{c}-0.192^{* *} \\
(0.0849)\end{array}$ & $\begin{array}{c}-0.193^{* *} \\
(0.0778)\end{array}$ & $\begin{array}{c}-0.175^{* *} \\
(0.0799)\end{array}$ & $\begin{array}{c}-0.175^{* *} \\
(0.0815)\end{array}$ & $\begin{array}{c}-0.180^{* *} \\
(0.0761)\end{array}$ & $\begin{array}{r}-0.197^{* *} \\
(0.0766)\end{array}$ \\
\hline FCLqual_lnFCC & $\begin{array}{l}-0.0212 \\
(0.0190)\end{array}$ & & & & & & & \\
\hline FCLqual_A_lnFCC & & $\begin{array}{c}-0.00504 \\
(0.0144)\end{array}$ & & & & & & \\
\hline FCLqual_B_lnFCC & & & $\begin{array}{c}0.0110 \\
(0.0201)\end{array}$ & & & & & \\
\hline FCLqual_C_lnFCC & & & & $\begin{array}{c}0.00906 \\
(0.0222)\end{array}$ & & & & \\
\hline FCLqual_D_lnFCC & & & & & $\begin{array}{c}-0.0120 \\
(0.0172)\end{array}$ & & & \\
\hline FCLqual_E_lnFCC & & & & & & $\begin{array}{c}-0.0113 \\
(0.0208)\end{array}$ & & \\
\hline FCLqual_F_lnFCC & & & & & & & $\begin{array}{c}-0.00319 \\
(0.0170)\end{array}$ & \\
\hline FCLqual_G_lnFCC & & & & & & & & $\begin{array}{c}0.0136 \\
(0.0191)\end{array}$ \\
\hline _cons & $\begin{array}{c}28.11^{* * *} \\
(2.297)\end{array}$ & $\begin{array}{c}28.22^{* * *} \\
(2.303)\end{array}$ & $\begin{array}{c}28.23^{* * *} \\
(2.296)\end{array}$ & $\begin{array}{c}28.27^{* * *} \\
(2.306)\end{array}$ & $\begin{array}{c}28.15^{* * *} \\
(2.283)\end{array}$ & $\begin{array}{c}28.17^{* * *} \\
(2.307)\end{array}$ & $\begin{array}{c}28.23^{* * *} \\
(2.333)\end{array}$ & $\begin{array}{c}28.30^{* * *} \\
(2.318)\end{array}$ \\
\hline adj. $R^{2}$ & 0.523 & 0.521 & 0.521 & 0.521 & 0.521 & 0.521 & 0.521 & 0.522 \\
\hline VIF & 1.293 & 1.609 & 1.903 & 1.629 & 1.516 & 1.468 & 1.400 & 1.581 \\
\hline$N$ & 4627 & 4627 & 4627 & 4627 & 4627 & 4627 & 4627 & 4627 \\
\hline
\end{tabular}

Fixed-effect regression. Standard errors in parentheses.

${ }^{*} p$-value $<0.1,{ }^{* *} p$-value $<0.05,{ }^{* * *} p$-value $<0.01$

Dependent variable: log of monthly EMBIG spread.

For a description of the variables, see Table 4. 